\title{
Pancreatic beta cell line MIN6 exhibits characteristics of glucose metabolism and glucose-stimulated insulin secretion similar to those of normal islets
}

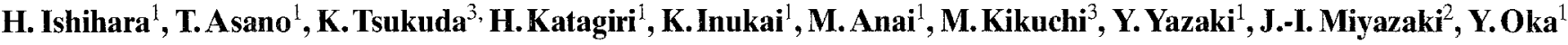 \\ ${ }^{1}$ Third Department of Internal Medicine, Faculty of Medicine, University of Tokyo, Tokyo, Japan \\ ${ }^{2}$ Department of Disease-Related Gene Regulation Research (Sandoz), Faculty of Medicine, University of Tokyo, Tokyo, Japan \\ ${ }^{3}$ Institute for Adult Disease, Asahi Life Foundation, Tokyo, Japan
}

\begin{abstract}
Summary. Glucose-stimulated insulin secretion, glucose transport, glucose phosphorylation and glucose utilization have been characterized in the insulinoma cell line MIN6, which is derived from a transgenic mouse expressing the large T-antigen of SV40 in pancreatic beta cells. Glucosestimulated insulin secretion occurred progressively from $5 \mathrm{mmol} / \mathrm{l}$ glucose, reached the maximal level approximately seven-fold above the basal level at $25 \mathrm{mmol} / \mathrm{l}$, and remained at this level up to $50 \mathrm{mmol} / \mathrm{l}$. Glucose transport was very rapid with the half-maximal uptake of 3-O-methyl-D-glucose being reached within $15 \mathrm{~s}$ at $22^{\circ} \mathrm{C}$. Glucose phosphorylating activity in the cell homogenate was due mainly to glucokinase; the $\mathrm{V}_{\max }$ value of glucokinase activity was estimated to be $255 \pm 37 \mathrm{nmol} \cdot \mathrm{h}^{-1} \cdot \mathrm{mg}$ protein ${ }^{-1}$, constituting approximately $80 \%$ of total phosphorylating activity, whereas hexokinase
\end{abstract}

activity constituted less than $20 \%$. MIN6 cells exhibited mainly the high $\mathrm{K}_{\mathrm{m}}$ component of glucose utilization with a $\mathrm{V}_{\max }$ of $289 \pm 18 \mathrm{nmol} \cdot \mathrm{h}^{-1} \cdot \mathrm{mg}$ protein ${ }^{-1}$. Thus, glucose utilization quantitatively and qualitatively reflected glucose phosphorylation in MIN6 cells. In contrast, MIN7 cells, which exhibited only a small increase in insulin secretion in response to glucose, had 4.7-fold greater hexokinase activity than MIN6 cells with a comparable activity of glucokinase. These characteristics in MIN6 cells are very similar to those of isolated islets, indicating that this cell line is an appropriate model for studying the mechanism of glucose-stimulated insulin secretion in pancreatic beta cells.

Key words: Clonal beta-cell line, insulin secretion, glucose transport, glucose phosphorylation, glucose utilization.
Impaired glucose-stimulated insulin secretion from pancreatic beta cells is thought to be one of the major causes of Type 2 (non-insulin-dependent) diabetes mellitus. Many investigations have therefore attempted to elucidate the mechanism of insulin secretion triggered by an elevated extracellular glucose concentration. However, the precise mechanism by which glucose stimulates insulin secretion from pancreatic beta cells has yet to be determined. Cellular heterogeneity and the limited availability of pancreatic islets have made progress in the field difficult.

Recent advances in gene manipulation technology provide tools for understanding cellular mechanisms. Clonal cell lines are preferable for these gene manipulations. Recently, we established an insulinoma cell line derived from a transgenic mouse, the MIN6 cell line. The amount of insulin secreted at $25 \mathrm{mmol} / \mathrm{l}$ glucose was six- to seven-fold higher than that obtained at $5 \mathrm{mmol} / \mathrm{l}$ glucose, suggesting that glucose-stimulated insulin secretion in MIN6 cells may retain a concentration dependence similar to that of normal islets [1]. In contrast, other reported insulin-producing cell lines such as RINm5F [2, 3], RINr [4], NIT-1
[5], $\beta \mathrm{TC}-1[6,7], \beta \mathrm{TC}-3$ [6, 8], IgSV195 [9], and HIT cells [10] do not respond to glucose, or respond at much lower glucose concentrations ( 1 to $5 \mathrm{mmol} / \mathrm{l})$ than do normal islets. Although a recently developed cell line, INS-1, seemed to respond to the physiological range of glucose, only a 2.2-fold increase in insulin secretion was observed at a high glucose concentration [11]. Abnormal properties of glucose transport and/or phosphorylation have been reported for RINm5 F [2,3,12-14, 15], RINr [12], $\beta \mathrm{TC}-1$ [7], $\beta$ TC-3 [8], IgSV195 [15], and HIT [15, 16] cells, leading to characteristics of glucose utilization which differ from those of normal pancreatic beta cells.

Considerable evidence has been collected that the glucose signal for insulin secretion is generated by glucose metabolism in beta cells $[17,18]$. Recent studies have shown that glucose transport and phosphorylation steps are important for glucose-stimulated insulin secretion in pancreatic beta cells [18-20]. The present study was designed to characterize the properties of glucose transport, phosphorylation, utilization and glucose-stimulated insulin secretion in MIN6 cells and to determine whether MIN6 cells represent an appropriate model for investigat- 
ing the mechanism of glucose-stimulated insulin secretion. The results indicate that glucose metabolism and the glucose concentration dependence of insulin secretion in MIN6 cells closely resemble those in normal beta cells, and that this cell line is thus a useful tool for studying glucose-stimulated insulin secretion in normal pancreatic beta cells.

\section{Materials and methods}

Cell culture: MIN6 cells were grown in Dulbecco's modified Eagle's medium (DMEM, $25 \mathrm{mmol} / \mathrm{l}$ glucose) equilibrated with $5 \% \mathrm{CO}_{2}$ and $95 \%$ air at $37^{\circ} \mathrm{C}$. The medium was supplemented with $15 \%$ fetal calf serum, $50 \mathrm{mg} / 1$ streptomycin and $75 \mathrm{mg} / \mathrm{l}$ penicillin sulphate. MIN6 cells used in the present study were harvested at passages $16-$ 23.

Insulin secretion and insulin content assay. Insulin secretion was determined using a static incubation method in $5 \% \mathrm{CO}_{2}$ and $95 \%$ air at $37^{\circ} \mathrm{C}$. Two $\times 10^{5}$ cells were seeded in $1 \mathrm{ml} \mathrm{DMEM}(25 \mathrm{mmol} / \mathrm{glu}-$ cose) in 24-well plates. After $48 \mathrm{~h}$ of culture, the medium was removed and cells were washed once with HEPES-balanced KrebsRinger bicarbonate buffer $(119 \mathrm{mmol} / 1 \mathrm{NaCl}, 4.74 \mathrm{mmol} / 1 \mathrm{KCl}$, $2.54 \mathrm{mmol} / 1 \quad \mathrm{CaCl}_{2}, 1.19 \mathrm{mmol} / 1 \quad \mathrm{MgCl}_{2}, 1.19 \mathrm{mmol} / \mathrm{l} \quad \mathrm{KH}_{2} \mathrm{PO}_{4}$, $25 \mathrm{mmol} / \mathrm{l} \mathrm{NaHCO}, 10 \mathrm{mmol} / \mathrm{l}$ HEPES, $\mathrm{pH} 7.4$ ) containing $0.5 \%$ bovine serum albumin (BSA) without glucose. Next, cells were preincubated for $0.5 \mathrm{~h}$ in HEPES-balanced Krebs-Ringer bicarbonate buffer with $0.5 \% \mathrm{BSA}$ and $5 \mathrm{mmol} / \mathrm{l}$ glucose. After washing twice with HEPES-balanced Krebs-Ringer bicarbonate buffer, MIN6 cells were incubated for $2 \mathrm{~h}$ in HEPES-balanced Krebs-Ringer bicarbonate buffer supplemented with $0.5 \% \mathrm{BSA}$ and varying concentrations of glucose. The media were then collected and assayed for immunoreactive insulin by RIA using rat insulin as a standard. To each well $200 \mu \mathrm{l}$ of $1 \mathrm{~mol} / \mathrm{l} \mathrm{NaOH}$ was added to solubilize cells for determination of cellular protein content with a Bio-Rad protein assay kit. For measurement of cellular insulin content, $1 \mathrm{mI}$ of acid ethanol was added to the wells which were then sealed with pressuresensitive film. The extract was collected after $24-\mathrm{h}$ incubation at $4^{\circ} \mathrm{C}$, diluted and assayed by RIA.

3-O-methyl-D-glucose transport: The method of Johnson et al. [21] was employed. MIN6 cells were detached by treatment with phosphate-buffered saline (PBS) containing $0.5 \mathrm{mmol} / 1$ EDTA for $5 \mathrm{~min}$ and incubated in PBS containing $2 \mathrm{mmol} / \mathrm{l}\left[{ }^{14} \mathrm{C}\right]$ urea $(0.25$ $\mathrm{mCi} / \mathrm{mmol}$ ) as an intracellular space marker at $37^{\circ} \mathrm{C}$ for $20 \mathrm{~min}$, followed by incubation at $22^{\circ} \mathrm{C}$ for $10 \mathrm{~min}$. Fifty microlitres of $1 \mathrm{~mol} / 1$ glucose containing $10 \mathrm{mmol} / /$ EDTA and $0.1 \%$ SDS (pH 8.0) was placed in the bottom of a $400 \mu \mathrm{l}$ microfuge tube. This solution was overlaid with $150 \mu$ l of a dibutyl phthalate-dinonyl phthalate (4:1) mixture. Fifty microlitres of PBS containing $2 \mathrm{mmol} / 1\left[{ }^{14} \mathrm{C}\right]$ urea $(0.25 \mathrm{mCi} / \mathrm{mmol})$ and $\left.20 \mathrm{mmol} / \mathrm{l} 3-\mathrm{O}-{ }^{3} \mathrm{H}\right]$ methyl-D-glucose $(2.5$ $\mathrm{mCi} / \mathrm{mmol}$ ) was layered over the dibutyl phthalate-dinonyl phthalate phase. The tubes were then preincubated for $30 \mathrm{~min}$ at $22^{\circ} \mathrm{C}$. Uptake was initiated by addition of $50 \mu \mathrm{l}$ of the cell suspension to the PBS layer containing labelled urea and 3-O-methyl-D-glucose. Uptake was terminated by centrifugation of the tubes for $15 \mathrm{~s}$ so that cells were sedimented to the $1 \mathrm{~mol} / 1$ glucose- $10 \mathrm{mmol} / 1$ EDTA$0.1 \%$ SDS solution. Then tubes were cut at the dibutyl phthalatedinonyl phthalate layer and the part containing sedimented cells was used for determination of the uptake and the intracellular space. The uptake of $\mathrm{L}-\left[1-{ }^{3} \mathrm{H}\right]$ glucose was measured by the same procedure. Uptake was determined in quadruplicate at each concentration.

Glucose phosphorylation. Glucose phosphorylating activity was determined by the method of Trus et al. [18]. MIN6 cells were harvested with trypsin-EDTA, washed with PBS twice to remove glu- cose and homogenized with 7 strokes in a homogenizing buffer $\left(20 \mathrm{mmol} / \mathrm{l} \mathrm{K}_{2} \mathrm{HPO}_{4}, 5 \mathrm{mmol} / 1\right.$ dithiothreitol, $1 \mathrm{mmol} / \mathrm{l} \mathrm{EDTA}$, and $110 \mathrm{mmol} / 1 \mathrm{KCl}, \mathrm{pH} 7.4)$ using a Potter-Elvehjem glass-Teflon homogenizer. A half aliquot of the homogenate was centrifuged at $12000 \times g$ for $10 \mathrm{~min}$ at $4^{\circ} \mathrm{C}$ and the supernatant was removed. Glucose phosphorylating activity and protein concentration were determined in both the homogenate and the supernatant. The superna-

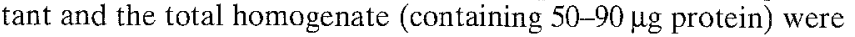
incubated for $90 \mathrm{~min}$ at $30^{\circ} \mathrm{C}$ in the buffer containing $50 \mathrm{mmol} / \mathrm{l}$ $\mathrm{HEPES}, 100 \mathrm{mmol} / \mathrm{KCl}, 7.4 \mathrm{mmol} / \mathrm{l} \mathrm{MgCl} 2,15 \mathrm{mmol} / 1 / \beta$-mercaptoethanol, $0.5 \mathrm{mmol} / 1 \mathrm{NAD}^{+}, 0.05 \%$ BSA, $0.7 \mathrm{uni} / \mathrm{ml}$ glucose $6-$ phosphate dehydrogenase from Leuconostoc mesenteroides, $5 \mathrm{mmol} / \mathrm{ATP}$ and varying concentrations of glucose $(0.06,0.15,0.3$, $0.6,1,6,10,15,30,60$, and $100 \mathrm{mmol} / \mathrm{l})$. The reaction was terminated

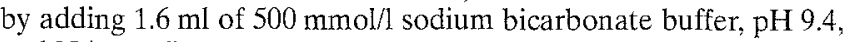
and NADH fluorescence was then measured. Phosphorylating activity was determined in triplicate at each concentration. In each assay, reagent blanks and tissue blanks were included. Reagent blanks consisted of assay reagents with either 0.6 or $60 \mathrm{mmol} / \mathrm{l} \mathrm{glu-}$ cose in the absence of tissue. The experiments of tissue blanks were performed by incubation of tissue with either 0.6 or $60 \mathrm{mmol} / 1 \mathrm{glu}-$ cose in the absence of ATP. Fluorescence of both reagent blanks and tissue blanks was subtracted from the total fluorescence observed with a complete reagent with tissue. $V_{\max }$ and $\mathrm{K}_{\mathrm{m}}$ for glucose were determined by analysis of the data with Eadie-Hofstee plots. On the Eadie-Hofstee plots, the least-squares method was used to draw a best-fitted line.

Glucose utilization. Glucose utilization was measured by following the conversion of $\left[5^{3} \mathrm{H}\right]$ glucose into ${ }^{3} \mathrm{H}_{2} \mathrm{O}$ [18]. MIN6 cells were seeded and preincubated using the same procedures as those used for the determination of insulin secretion. Cells were then incubated at $37^{\circ} \mathrm{C}$ in $0.3 \mathrm{ml}$ of HEPES-balanced Krebs-Ringer bicarbonate buffer with $0.5 \%$ BSA and varying concentrations of glucose $(0.15$, $0.3,0.6,1.0,5.0,10,15,25$ and $50 \mathrm{mmol} / 1)$ containing $5 \mu \mathrm{Ci} / \mathrm{ml}$ and $20 \mu \mathrm{Ci} / \mathrm{ml}\left[5-{ }^{3} \mathrm{H}\right] \mathrm{glucose}$ for lower $(\leq 1 \mathrm{mmol} / \mathrm{l})$ and higher $(\geq$ $5 \mathrm{mmol} / \mathrm{l}$ ) glucose concentrations, respectively. As blanks, $0.3 \mathrm{ml}$ of media alone were incubated in parallel. After a 2 -h incubation period, $0.1 \mathrm{ml}$ of the incubation media was removed to a microtube and mixed with $20 \mu \mathrm{l}$ of $1 \mathrm{~mol} / 1 \mathrm{HCl}$. The microtubes were then placed in $22-\mathrm{ml}$ plastic scintillation vials containing $0.6 \mathrm{ml}$ of distilled water. The vials were sealed and kept at $37^{\circ} \mathrm{C}$ for $36 \mathrm{~h}$ to allow the ${ }^{3} \mathrm{H}_{2} \mathrm{O}$ in the microtube to equilibrate with the water in the scintillation vial. Subsequently, the microtube was taken out and $10 \mathrm{ml}$ of ACS II (Amersham Japan, Tokyo, Japan) was added to each vial. The rate of glucose utilization was calculated using the formula described by Ashcroft et al. [22]. Under these experimental conditions, the recovery from known amounts of ${ }^{3} \mathrm{H}_{2} \mathrm{O}$ was $87 \pm 4 \%(n=3)$. Cellular protein content was determined after solubilizing cells with $200 \mu \mathrm{l}$ of $1 \mathrm{~mol} / \mathrm{l} \mathrm{NaOH}$.

Northern blot analysis. Total RNA was prepared using the guanidine isothiocyanate method. RNA was denatured with formaldehyde, separated by $1.0 \%$ agarose gel electrophoresis, and transferred onto Biodyne B nylon membranes (Pall BioSupport, Glen Cove, NY, USA). EcoT14I fragments of rat glucokinase cDNA (nucleotide $570-1616$ ) were ${ }^{32}$ P-labelled by random priming. Hybridization of the filters with the probe was carried out in $50 \%$ formamide, $5 \times \mathrm{SSC}(1 \times \mathrm{SSC}=150 \mathrm{mmol} / \mathrm{l} \mathrm{NaCl}, 15 \mathrm{mmol} / \mathrm{l}$ sodium citrate $)$, $5 \times$ Denhardt's solution $(1 \times$ Denhardt's solution $=0.02 \%$ polyvinyl pyrrolidone, $0.02 \%$ Ficoll, $0.02 \%$ BSA), $50 \mathrm{mmol} / \mathrm{l}$ sodium phosphate buffer, pH 7.0, 0.1\% SDS and $100 \mu \mathrm{g} / \mathrm{ml}$ salmon sperm DNA at $42^{\circ} \mathrm{C}$. The filters were washed with $0.2 \%$ SDS, $0.5 \times$ SSC at $60^{\circ} \mathrm{C}$ for $30 \mathrm{~min}$ and subjected to autoradiography.

\section{Statistical analysis}

Data are presented as mean $\pm \mathrm{SD}$, unless otherwise stated. Student's unpaired $t$-test was used to test for differences. 


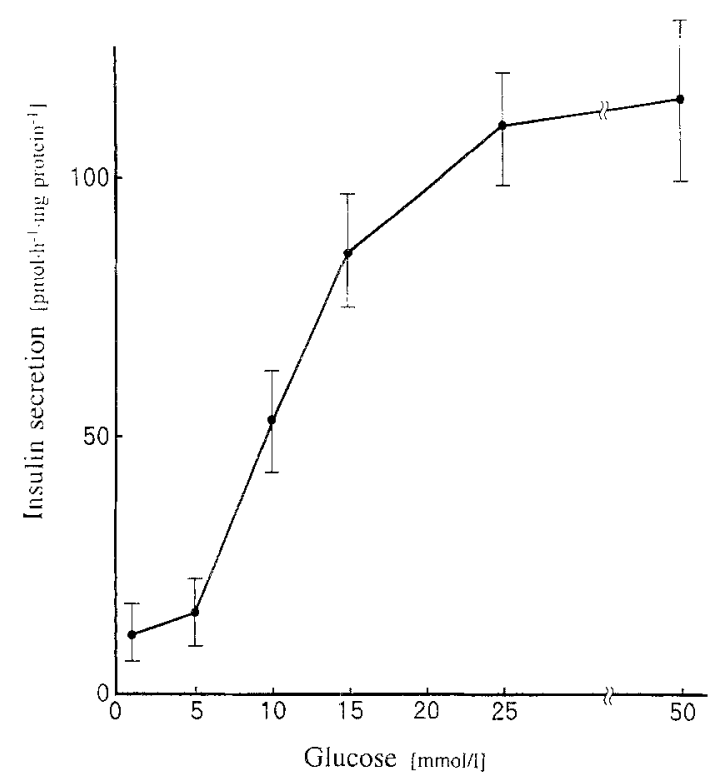

Fig. 1. Glucose-stimulated insulin secretion from MIN6 cells. Secreted insulin was measured in the medium after a 120 -min incubation of MIN6 cells in the presence of the indicated concentrations of glucose. Data are expressed per mg cellular protein, extracted by solubilizing cells with $1 \mathrm{~mol} / 1 \mathrm{NaOH}$. Values are mean $\pm \operatorname{SD}(n=4)$

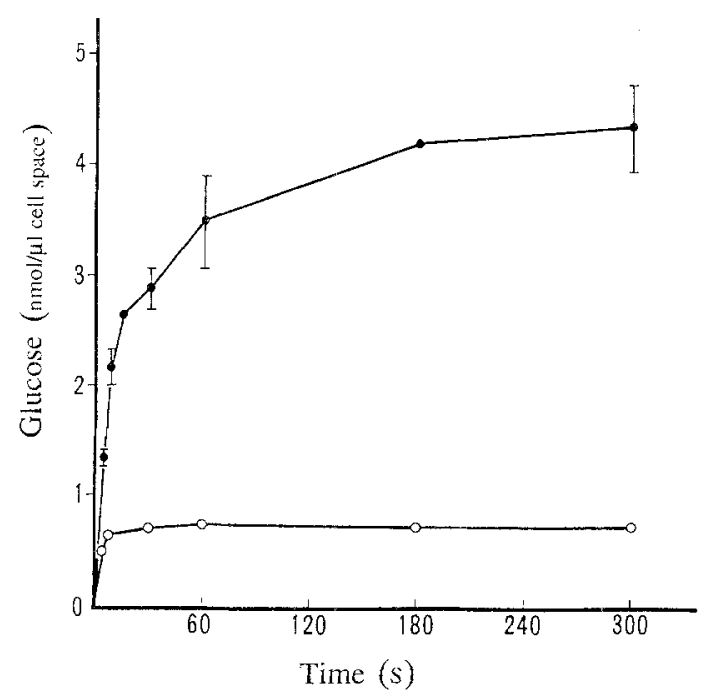

Fig. 2. Time course of the uptake of 3-O-methyl-glucose $(\bullet)$ and Lglucose (O) by MIN6 cells. Experiments were performed at a hexose concentration of $10 \mathrm{mmol} / \mathrm{l}$ at $22^{\circ} \mathrm{C}$. Each point with an error bar is mean \pm SEM of three separate experiments and those without an error bar are the means of two separate experiments

\section{Results}

\section{Glucose-dependence of insulin secretion}

Insulin content in MIN6 cells was $3230 \pm 690$ pmol insulin per $\mathrm{mg}$ cellular protein $(n=4)$. This value was calculated to be $1010 \mathrm{pmol} \cdot 10^{6}$ cells $^{-1}$, since the cellular protein content averaged $320 \pm 42 \mu \mathrm{g} \cdot 10^{6}$ cells $^{-1}(n=4)$. This amount is approximately $20 \%$ of the insulin content of mouse islet cells [23] and is comparable with that of recently established INS-1 cells [11]. Insulin secretion from MIN6 cells was increased when the extracellular glucose concentration exceeded $5 \mathrm{mmol} / \mathrm{l}$ and the half-maximum response was achieved at around
$10 \mathrm{mmol} / \mathrm{l}$ glucose (Fig. 1). The amount of secreted insulin at $25 \mathrm{mmol} / \mathrm{glucose}$ was approximately seven-fold greater than that at $5 \mathrm{mmol} / \mathrm{l}$.

\section{Glucose transport in MIN6 cells}

The uptake of 3-O-methyl-D-glucose by MIN6 cells was rapid, as shown in Figure 2. The time required for the halfmaximal uptake was less than $15 \mathrm{~s}$ and equilibration of the intracellular 3-O-methyl-D-glucose space was approximately $80 \%$ complete in 1 min at $22^{\circ} \mathrm{C}$. The distribution space of 3-O- $\left[{ }^{3} \mathrm{H}\right]$ methyl-D-glucose over 5 -min incubation was $0.70 \pm 0.10$ picolitre per cell $\left(\mathrm{pl} \cdot\right.$ cell $\left.^{-1}\right)(n=3)$, whereas $\left[{ }^{14} \mathrm{C}\right]$ urea distribution space over $30 \mathrm{~min}$ incubation was $1.78 \pm 0.23 \mathrm{pl} \cdot \operatorname{cell}^{-1}(n=3)$. No significant increase in Lglucose uptake was observed during 5-min incubation, indicating that $\mathrm{L}$-glucose in the cell pellets represented Lglucose trapped in the extracellular, rather than the intracellular, space. This L-glucose distribution space was 0.12 $\mathrm{pl} \cdot \mathrm{cell}^{-1}$ (mean of the results of two experiments). Intracellular 3-O-methyl-D-glucose space was estimated by subtracting $\mathrm{L}$-glucose distribution space from 3-O-methyl$\mathrm{D}$-glucose distribution space. Although it is not clear why the distribution space of 3-O-[$\left.{ }^{3} \mathrm{H}\right]$ methyl-D-glucose was smaller than that of $\left[{ }^{14} \mathrm{C}\right]$ urea in MIN6 cells, similar discrepancy was observed between the distribution space of glucose and that of urea in isolated islets [24]. It may be possible that the urea distribution space represents two or more intracellular compartments, one of which is intracellular 3-O-methyl-D-glucose space. These results on glucose uptake suggest that MIN6 cells contain a transport system with very high activity specific for D-glucose.

\section{Expression of glucokinase in MIN6 cells}

Total RNA from mouse brain, liver and MIN6 cells were probed with a rat glucokinase cDNA fragment (Fig. 3). An approximately 2.4 kilobase $(\mathrm{kb})$ glucokinase mRNA was expressed in liver tissue, as reported previously [25], and an approximately $2.8 \mathrm{~kb}$ mRNA, slightly larger than the liver glucokinase mRNA, was detected in MIN6 cells. The size of this mRNA was identical to that reported previously for rat glucokinase mRNA in pancreatic islets [25]. Furthermore, amplification of glucokinase mRNA in MIN6 cells was performed by reverse transcription and

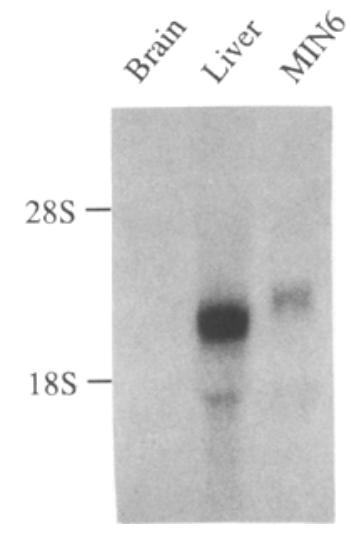

Fig. 3. Expression of glucokinase mRNA in MIN6 cells. Total RNA was extracted from $\mathrm{C} 57 \mathrm{BL} / 6$ mouse brain, liver, and MIN6 cells. $20 \mu \mathrm{g}$ (brain, liver) or $5 \mu \mathrm{g}$ (MIN6) of total RNA were electrophoresed in a $1.0 \%$ formaldehyde/agarose gel, transferred to a nylon membrane, and hybridized with rat glucokinase cDNA probe 


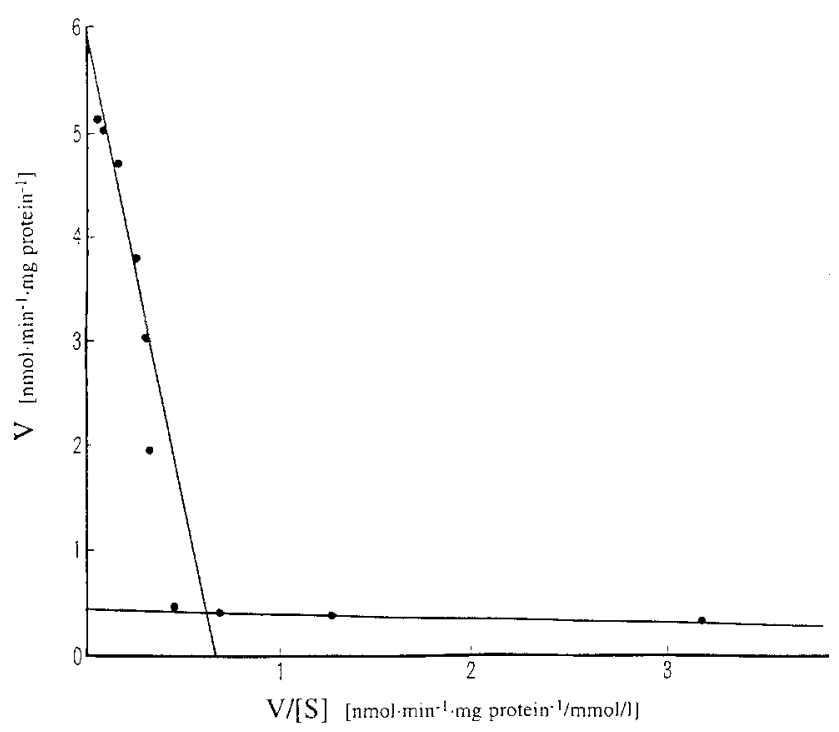

Fig. 4. Eadie-Hofstee plots for kinetic analysis of glucokinase and hexokinase activity in the supernatant of the MIN6 cell homogenate. Each point is the mean of triplicate measurements performed at $30^{\circ} \mathrm{C}$. A representative result from one of three independent experiments is shown. V, Reaction velocity; $\mathrm{S}$, substrate concentration

polymerase chain reaction using a sense oligonucleotide corresponding to nucleotide 411 to 430 and an antisense oligonucleotide corresponding to nucleotide 659 to 678 of mouse glucokinase cDNA [26]. A 268 base-pair DNA fragment, of the expected size, was obtained and sequencing of the DNA fragment demonstrated that the deduced first 15 amino acid residues were identical to those of rat islet glucokinase (data not shown).

\section{Glucose phosphorylating activity in the homogenate of MIN6 cells}

Because a fraction of hexokinase may be bound to cytoplasmic organelles, glucose phosphorylating activity was measured both in the total cell homogenate and in the supernatant of the homogenate. The representative Eadie-Hofstee plots of glucose phosphorylating activity in the supernatant are shown in Figure 4. The Eadie-Hofstee plots revealed two components of glucose phosphorylating activity; glucokinase and hexokinase activity. The result at $6 \mathrm{mmol} / \mathrm{l}$ glucose deviated from the high $\mathrm{K}_{\mathrm{m}}$ component, possibly reflecting a deviation in glucokinase kinetics from those of Michaelis-Menten model, i.e. glucokinase activity was lower than that expected from the Mi-

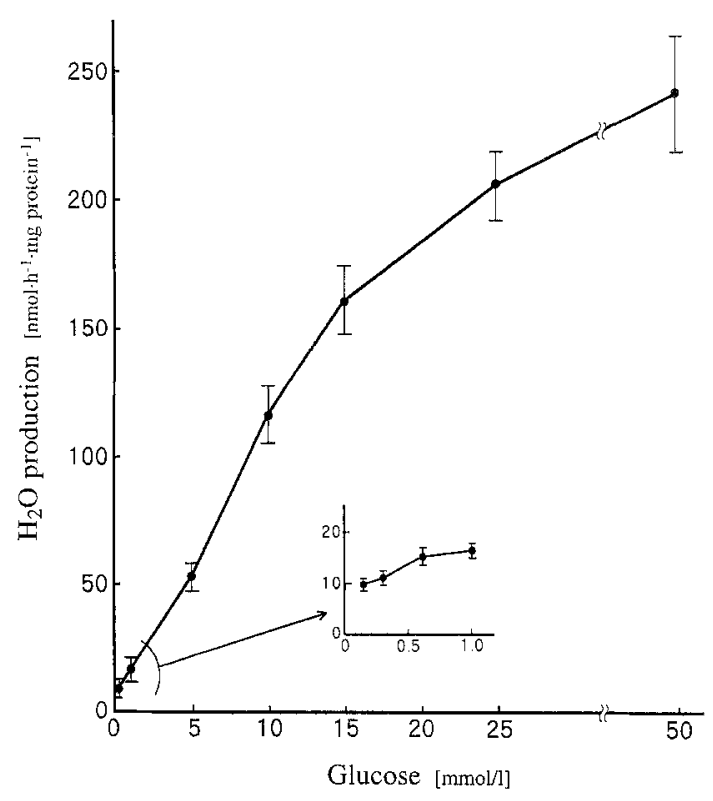

Fig. 5. Glucose utilization by MIN6 cells. Glucose utilization was measured by following the conversion of $\left[5-{ }^{3} \mathrm{H}\right]$ glucose into ${ }^{3} \mathrm{H}_{2} \mathrm{O}$ as described in Materials and methods. Data are expressed as the mean $\pm \mathrm{SD}$ of three independent experiments, performed in triplicate for each concentration

chaelis-Menten model at $6 \mathrm{mmol}$ glucose. Kinetic parameters of glucose phosphorylating activity in MIN6 cells are summarized in Table 1. Glucokinase constituted approximately $80 \%$ and $90 \%$ of glucose phosphorylating activity in the total homogenate and in its supernatant of MIN6 cells, respectively. For a comparison, we measured glucose phosphorylating activity in the homogenate of MIN7 cells which exhibited only a small increase in insulin secretion in response to glucose despite the considerable levels of GLUT 2 expression [1]. MIN7 cells also had two components of glucose phosphorylating activity; glucokinase activity with $V_{\max }$ of $1.91 \pm 0.29 \mathrm{nmol} \cdot \mathrm{min}^{-1} \cdot \mathrm{mg}$ protein $^{-1}$ and $\mathrm{K}_{\mathrm{m}}$ of $12.4 \pm 1.73 \mathrm{mmol} / \mathrm{l}$ and hexokinase activity with $\mathrm{V}_{\max }$ of $2.31 \pm 0.14 \mathrm{nmol} \cdot \mathrm{min}^{-1} \cdot \mathrm{mg}$ protein ${ }^{-1}$ and $\mathrm{K}_{\mathrm{m}}$ of $0.046 \pm 0.012 \mathrm{mmol} / \mathrm{l}(n=3)$. Thus, MIN7 cells have 4.7-fold higher hexokinase activity than MIN6 cells. MIN6 cells tend to have a higher glucokinase activity than MIN7 cells but the difference was not significant ( $p=0.074$ ).

\section{Glucose utilization in MIN6 cells}

Glucose utilization was studied at $0.15-50 \mathrm{mmol} / \mathrm{l}$ glucose concentrations. Glucose utilization by MIN6 cells exhibited a small increase in the range of $0.15-1 \mathrm{mmol} / \mathrm{lglu}-$

Table 1. Kinetic characteristics of glucokinase and hexokinase in MIN6 cells

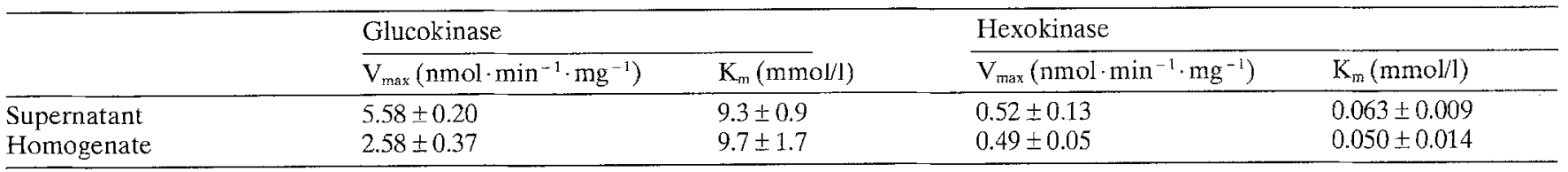

Values are mean $\pm \mathrm{SD}, n=3$ 
cose $\left(9.78 \pm 1.03 \mathrm{nmol} \cdot \mathrm{h}^{-1} \cdot \mathrm{mg}\right.$ protein ${ }^{-1}$ at $0.15 \mathrm{mmol} / 1$ glucose vs $16.5 \pm 3.14$ at $1.0 \mathrm{mmol} / \mathrm{l}$ glucose $(n=3)$, $p<0.05$ ) with a marked stimulation at glucose concentrations greater than $5 \mathrm{mmol} / \mathrm{l}$ (Fig. 5). Eadie-Hofstee plots for these data could be resolved into two linear components; one with low $\mathrm{K}_{\mathrm{m}}$ (apparent $\mathrm{K}_{\mathrm{m}}=0.257 \pm$ $0.032 \mathrm{mmol} / 1, \quad V_{\max }=20.8 \pm 4.2 \mathrm{nmol} \cdot \mathrm{h}^{-1} \cdot \mathrm{mg}$ protein ${ }^{-1}$, $n=3$ ) and the other with high $\mathrm{K}_{\mathrm{m}}$ (apparent $\mathrm{K}_{\mathrm{m}}=15.4 \pm 0.75 \mathrm{mmol} / 1, \quad \mathrm{~V}_{\max }=289 \pm 18 \mathrm{nmol} \cdot \mathrm{h}^{-1} \cdot \mathrm{mg}$ protein $^{-1}, n=3$ ).

\section{Discussion}

Glucose-sensing is a very important function of pancreatic beta cells and serves to maintain an appropriate blood glucose level. Impairment of glucose-sensing by beta cells results in an alteration in the glucose concentration dependence of insulin secretion in pancreatic beta cells, which may lead to Type 2 diabetes [27, 28]. Many lines of evidence have suggested that the glucose signal for insulin secretion is generated by the metabolism of transported glucose in beta cells. In this report, we have characterized the properties of transport, phosphorylation, and utilization of glucose in MIN6 cells and have demonstrated that these characteristics are very similar to those in normal pancreatic islets and beta cells.

The glucose concentration dependence of insulin secretion in MIN6 cells resembled that of isolated islets from rats [2,29] and mice [30]. The fold-increase at a high glucose concentration is, however, lower in MIN6 cells (7.3-fold) compared with that in isolated mouse islets $(\sim 10-25$-fold $)[30,31]$. One of the reasons for the lower fold-increase in MIN6 cells may be a lack of suppression of insulin secretion by non-beta cells at a low glucose concentration. Reaggregated purified beta cells were reported to exhibit an enhanced insulin secretion compared with that of intact islets at a low glucose concentration, and thus the fold-increase in purified beta cells was smaller than that in islets and was comparable to that in MIN6 cells [32].

Glucose transport by MIN6 cells was very rapid, as in isolated islet cells of rats [21] and mice [33]. It has been reported that RINm5F [12-14], RINr [12] and HIT cells [12, 15], which did not respond to an elevated glucose concentration or responded only at much lower concentrations than the physiological level, exhibit a slow rate of glucose uptake. Interestingly, these clonal beta-cell lines have also been reported to express a considerable amount of GLUT $1[26,34,35]$. In contrast, MIN6 cells and normal beta cells express a high level of GLUT 2 and a barely detectable level of GLUT $1[1,36,37]$. Although it is not clear whether high levels of GLUT 2 expression without GLUT 1 are needed for normal glucose-sensing, these data on glucose uptake suggest the importance of rapid glucose transport for normal glucose-sensing in pancreatic beta cells. Since the $\mathrm{V}_{\max }$ of GLUT 2 transport activity is much greater than that of GLUT 1 [38], the expression of GLUT 2 is advantageous for achieving a rapid glucose uptake. Glucose phosphorylating activity at $10 \mathrm{mmol} / 1$ glucose at $22^{\circ} \mathrm{C}$ was calculated to be $0.082 \mathrm{nmol} \cdot 15 \mathrm{~s}^{-1} \cdot 10^{6}$ cell $^{-1}$, using the results obtained at $30^{\circ} \mathrm{C}$ and a $\mathrm{Q}_{10}$ (correction factor) of 2 [39], whereas 3-O-methyl-D-glucose transport rate at $10 \mathrm{mmol} / \mathrm{lglucose}$ at $22^{\circ} \mathrm{C}$ was calculated to be 3.15 $\mathrm{nmol} \cdot 15 \mathrm{~s}^{-1} \cdot 10^{6} \mathrm{cell}^{-1}$. Thus, glucose transport rate was 38 fold greater than the rate of glucose phosphorylation in MIN6 cells.

Rapid glucose transport allows a rapid equilibration of intracellular and extracellular glucose concentrations. Thus, glucose phosphorylation progresses at the substrate concentration which is very similar to that of the extracellular space. In MIN6 cells, glucokinase is the major glucose phosphorylating enzyme, constituting about $80 \%$ of total glucose phosphorylating activity. A high glucokinase activity in MIN6 cells may be the result of culture at a high glucose concentration ( $25 \mathrm{mmol} / \mathrm{l})$, as glucokinase activity has been reported to be up-regulated by glucose [40]. It might be possible that an erroneously high glucokinase value could result if $\mathrm{N}$-acetylglucosamine kinase was present in MIN6 cells. $\mathrm{N}$-acetylglucosamine kinase was reported to exhibit glucose phosphorylating activity with a $\mathrm{K}_{\mathrm{m}}$ for glucose of $370 \mathrm{mmol} / \mathrm{l}$ [41]. However, the EadieHofstee plots for glucokinase were linear, suggesting that $\mathrm{N}$-acetylglucosamine kinase does not contribute significantly to phosphorylating activity in MIN6 cells.

Approximately $50 \%$ of the glucose phophorylating activity was attributable to hexokinase in $12000 \times \mathrm{g}$ supernatant of homogenate of isolated islets from rats and mice (data not shown), which is in accord with previous reports [42]. In contrast, only $10 \%$ of phosphorylating activity was attributed to hexokinase in MIN6 cells. Not only the relative value but also the absolute value of hexokinase activity was significantly lower in MIN6 cells $(0.52 \mathrm{nmol}$. $\mathrm{min}^{-1} \cdot \mathrm{mg}$ protein $\left.{ }^{-1}\right)$, as compared with the reported value in normal islets $\left(3.0 \mathrm{nmol} \cdot \mathrm{min}^{-1} \cdot \mathrm{mg}\right.$ protein $\left.{ }^{-1}\right)$ [42]. Despite a high level of hexokinase activity, the low $\mathrm{K}_{\mathrm{m}}$ component of glucose utilization was a minor component in normal islets (15\% of total glucose usage) $[18,22]$. One explanation for the apparent low activity of the low $\mathrm{K}_{\mathrm{m}}$ component of glucose utilization is that hexokinase is largely inhibited by glucose 6-phosphate in islets. However, another possibility is that a considerable amount of hexokinase is present in non-beta cells, but not in beta cells, and that glucose phosphorylation is not a rate-limiting step for glucose utilization in non-beta cells. Indeed, there is good evidence that the pancreatic alpha cells are less accessible to glucose than the beta cells and that glucose transport, rather than the glucose phosphorylation step, might be rate-limiting for glucose utilization in alpha cells $[43,44]$. If this is the case, the hexokinase content of pancreatic beta cells may be similar to that of MIN6 cells. Indeed, measurement of glucose phosphorylating activity in purified rat beta cells has suggested that hexokinase activity in beta cells was lower than the average value for cells of pancreatic islets [24]. It is interesting to note that in the liver, another tissue which expresses glucokinase, hexokinase activity is much greater in non-parenchymal cells than in hepatocytes [45].

Glucose utilization was much stimulated by glucose at concentrations greater than $5 \mathrm{mmol} / 1$ in MIN 6 cells. The glucose concentration dependence of insulin secretion correlated closely with that of glucose utilization in MIN6 
Table 2. Glucose-stimulated insulin secretion and glucose metabolism in various insulin-secreting cells

\begin{tabular}{|c|c|c|c|c|c|c|c|c|c|c|c|c|}
\hline \multirow{3}{*}{ Cell line } & \multirow{3}{*}{ Passage no. } & & & \multicolumn{4}{|c|}{ Insulin secretion } & \multirow{2}{*}{\multicolumn{2}{|c|}{$\begin{array}{l}\text { Glucose } \\
\text { phosphorylation }(\%)^{e}\end{array}$}} & \multirow{2}{*}{\multicolumn{3}{|c|}{$\begin{array}{l}\text { Glucose } \\
\text { utilization }(\%)^{\mathrm{f}}\end{array}$}} \\
\hline & & \multirow{2}{*}{\multicolumn{2}{|c|}{$\frac{\text { Insulin content }^{\mathrm{a}}}{\text { per protein per cell }}$}} & \multirow{2}{*}{$\begin{array}{l}\text { Basal }^{b} \\
(\% \text { content })\end{array}$} & \multirow{2}{*}{$\begin{array}{l}\text { Fold- } \\
\text { increase }^{c}\end{array}$} & \multicolumn{2}{|c|}{ GLUT isoforms $^{\mathrm{d}}$} & & & & & \\
\hline & & & & & & GLUT 1 & GLUT2 & low- $\mathrm{K}_{\mathrm{m}}$ & high- $\mathrm{K}_{\mathrm{m}}$ & low-Km & high-Km & Reference \\
\hline NIT-1 & 11 & & 265 & 45 & 1.5 & ND & ND & ND & ND & ND & ND & 5 \\
\hline$\beta$ ГC-1 & $63, ?$ & & 54 & $?$ & 2.5 & + & - & ND & ND & 58 & 42 & 6,7 \\
\hline$\beta$ ТС -3 & $17-35$ & 5330 & & 0.5 & 1.9 & + & - & ND & ND & ND & ND & 8 \\
\hline RINm5F & $?$ & & 2.5 & 22 & 1.2 & + & - & $\sim 100$ & $\sim 0$ & $\sim 100$ & $\sim 0$ & $2,3,16,34$ \\
\hline $\mathrm{RINr}$ & $8-9$ & & 14.6 & 2.0 & 4.5 & + & $\pm \sim+$ & ND & ND & ND & ND & 4,26 \\
\hline INS-1 & $9-83$ & & 1550 & 5.0 & 2.2 & ND & ND & ND & ND & ND & ND & 11 \\
\hline
\end{tabular}

${ }^{a}$ Insulin content was expressed as pmol per mg protein or pmol per

d - , No expression; \pm , low levels of expression; + , considerable $10^{6}$ cells

${ }^{\mathrm{b}}$ Insulin secretion per $1 \mathrm{~h}$ at a basal condition was expressed as \% of cellular insulin content

"Insulin secretion at a high glucose concentration was expressed as fold-increase relative to that at a basal condition

levels of expression

e $\%$ contribution of low- and high- $\mathrm{K}_{\mathrm{m}}$ system to total glucose phosphorylating activity in the supernatant of cell homogenates

$\mathrm{f} \%$ contribution of low- and high- $\mathrm{K}_{\mathrm{m}}$ system to glucose usage ND, Not determined

cells. A similar correlation was also observed in normal islets. The $\mathrm{V}_{\max }$ of glucokinase in the total homogenate of MIN6 cells at $37^{\circ} \mathrm{C}$ was calculated to be $255 \pm 37 \mathrm{nmol}$. $\mathrm{h}^{-1} \cdot \mathbf{m g}$ protein ${ }^{-1}(n=3)$, assuming that $\mathrm{Q}_{10}$ equals 2 [39]. This value is comparable to the $V_{\text {max }}$ of the high $\mathrm{K}_{\mathrm{m}}$ component of glucose utilization $\left(289 \pm 18 \mathrm{nmol} \cdot \mathrm{h}^{-1} \cdot \mathrm{mg}\right.$ protein $^{-1}, n=3$ ), suggesting that glucokinase may have a role in determining the rate of glycolysis in MIN6 cells, as suggested by results obtained in normal islets [18].

Properties of glucose-stimulated insulin secretion and glucose metabolism in MIN6 cells and other insulin secreting cell lines are summarized and compared with those of isolated islets (Table 2). Except for the cellular insulin content and the glucokinase/hexokinase ratio in the supernatant of the cell homogenate, MIN6 cells and normal islets exhibit common features in the insulin secretion and glucose metabolism. Important characteristics distinguishing MIN6 cells from other cell lines are ample levels of GLUT 2 with very low levels of GLUT 1 and a high glucokinase activity with a low hexokinase activity in MIN6 cells. MIN7 cells have greater expression levels of GLUT 1 [1] and 4.7-fold greater hexokinase activity compared with MIN6 cells, while MIN6 cells and MIN7 cells have comparable levels of GLUT 2 and glucokinase activity. Thus, high levels of GLUT 1 expression or hexokinase, or both, may deprive MIN7 cells of normal responsiveness to glucose. These data further support the view that glucose transport and/or glucose phosphorylation play an important role for normal glucose-sensing. However, other abnormalities downstream from glucose-phosphorylating step are also possible in MIN7 cells.

Our data suggest that cellular components regulating the glucose concentration dependence of insulin secretion in MIN6 cells resemble those in normal islets both quantitatively and qualitatively. Thus, the MIN6 cell is a suitable model for studying the mechanism of glucosestimulated insulin secretion. Further studies, in which these components are manipulated using molecular biological techniques, should help identify the mechanisms of glucose-stimulated insulin secretion in pancreatic beta cells.
Acknowledgements. We greatly appreciate Drs. I. Miwa and T. Murata (Meijo University, Nagoya) for their advice in measuring glucose phosphorylating activity and glucose utilization. This work was supported by a Grant-in-Aid for scientific research from the Ministry of Education, Science and Culture of Japan.

\section{References}

1. Miyazaki J-I, Araki K, Yamato E et al. (1990) Establishment of a pancreatic beta cell line that retains glucose-inducible insulin secretion: special reference to expression of glucose transporter isoforms. Endocrinology 127: 126-132

2. Halban PA, Praz GA, Wollheim CB (1983) Abnormal glucose metabolism accompanies failure of glucose to stimulate insulin release from a rat pancreatic cell line (RINm5 F) Biochem J 212: $439-443$

3. Giroix M-H, Sener A, Dufrane SP, Malaisse-Lagae F, Malaisse WJ (1985) Glucose metabolism in insulin-producing tumoral cells. Arch Biochem Biophys 241: 561-570

4. Clark SA, Burnham BL, Chick WL (1990). Modulation of glucose-induced insulin secretion from a rat clonal $\beta$-cell line. Endocrinology 127 : 2779-2788

5. Hamaguchi K, Gaskins HR, Leiter EH (1991) NIT-1, a pancreatic $\beta$-cell line established from a transgenic NOD/Lt mouse. Diabetes 40: 842-849

6. Efrat S, Linde S, Kofod $\mathrm{H}$ et al. (1988) Beta-cell lines derived from transgenic mice expressing a hybrid insulin gene-oncogene. Proc Natl Acad Sci USA 85: 9037-9041

7. Whitesell RR, Powers AC, Regan DM, Abumrad NA (1991) Transport and metabolism of glucose in an insulin-secreting cell line, $\beta$ TC-1. Biochemistry $30: 11560-11566$

8. D'Ambra R, Manju S, Efrat S, Starr RG, Fleischer N (1990) Regulation of insulin secretion from $\beta$-cell lines derived from transgenic mice insulinomas resembles that of normal $\beta$-cells. Endocrinology 126: 2815-2822

9. Gilligan A, Jewett L, Simon D et al. (1989) Functional pancreatic $\beta$-cell line from SV40 T-antigen transgenic mouse. Diabetes 38 : 1056-1062

10. Wang SY (1989) The acute effects of glucose on the insulin biosynthetic-secretory pathway in a Simian Virus 40-transformed hamster pancreatic islet $\beta$-cell line. Endocrinology 124: 19801987

11. Asfari M, Janjic D, Meda P, Li G, Halban PA, Wollheim CB (1992) Establishment of 2-mercaptoethanol-dependent differentiated insulin-secreting cell lines. Endocrinology 130: 167178 
12. Meglasson MD, Manning CD, Najafi H, Matschinsky FM (1986) Glucose transport by radiation-induced insulinoma and clonal pancreatic $\beta$-cells. Diabetes 35: 1340-1344

13. Malaisse WJ, Giroix M-H, Malaisse-Lagae F, Sener A (1986) 3O-methyl-D-glucose transport in tumoral insulin-producing cells. Am J Physiol 251: C841-C846

14. Trautmann ME, Wollheim CB (1987) Characterization of glucose transport in an insulin-secreting cell line. Biochem $\mathbf{J} 242$ : 625-630

15. Ashcroft SJH, Stubbs M(1987) The glucose sensor in HIT cells is the glucose transporter. FEBS Lett 219:311-315

16. Shimizu T, Knowles BB, Matschinsky FM (1988) Control of glucose phosphorylation and glucose usage in clonal insulinoma cells. Diabetes 37: 563-568

17. Grodsky GM, Batts AA, Bannett LL, Vcella C, McWilliams NB, Smith DF (1963) Effects of carbohydrates on secretion of insulin from isolated rat pancreas. Am J Physiol 205: 638-644

18. Trus MD, Zawalich WS, Burch PT, Berner DK, Weill VA, Matschinsky FM (1981) Regulation of glucose metabolism in pancreatic islets. Diabetes 30: 911-922

19. Unger R (1991) Diabetic hyperglycemia: link to impaired glucose transport in pancreatic beta cells. Science (Wash.DC) 251: $1200-1205$

20. Epstein PN, Boschero AC, Atwater I, Xingang C, Overbeek PA (1992) Expression of yeast hexokinase in pancreatic $\beta$ cells of transgenic mice reduces blood glucose, enhances insulin secretion, and decreases diabetes. Proc Natl Acad Sci USA 89: 1203812042

21. Johnson JH, Ogawa A, Chen L et al. (1990) The high $\mathrm{K}_{\mathrm{rn}}$ glucose transporter of islets of Langerhans is functionally similar to the low affinity transporter of liver and has an identical primary sequence. J Biol Chem 265: 6548-6551

22. Ashcroft SJH, Weerasinghe LCC, Bassett JM, Randle PJ (1972) The pentose cycle and insulin release in mouse pancreatic islets. Biochem J 126: 525-532

23. Lernmark $\AA$ (1974) The preparation of, and studies on, free cell suspensions from mouse pancreatic islets. Diabetologia 10: 431438

24. Giroix M-H, Sener A, Pipeleers DG, Malaisse WJ (1984) Hexose metabolism in pancreatic islets: inhibition of hexokinase. Biochem J 223: 447-453

25. Tiedge M, Lenzen S (1991) Regulation of glucokinase and GLUT-2 glucose transporter gene expression in pancreatic beta cells. Biochem J 279: 899-901

26. Hughes SD, Quaade C, Milburn JL, Cassidy L, Newgard CB (1991) Expression of normal and novel glucokinase mRNAs in anterior pituitary and islet cells. J Biol Chem 266: $4521-4530$

27. Vionnet N, Stoffel M, Takeda J et al. (1992) Nonsense mutation in the glucokinase gene causes early-onset non-insulin-dependent diabetes mellitus. Nature 356: 721-722

28. Katagiri H, Asano T, Ishihara H et al. (1992) Nonsense mutation of glucokinase gene in late-onset non-insulin-dependent diabetes mellitus. Lancet 340: 1316-1317

29. Sener A, Kawazu S, Hutton JC et al. (1978) The stimulus-secretion coupling of glucose-stimulated insulin release: effect of exogenous pyruvate on islet function. Biochem J 176:217-232

30. Lindström P (1984) Kinetics of 5-hydroxytryptophan potentiation of glucose-induced insulin release. Acta Endocrinol 106: $248-253$
31. Eizirik DL, Strandell E, Sandler S (1988) Culture of mouse pancreatic islets in different glucose concentrations modifies B cell sensitivity to streptozotocin. Diabetologia 31: 168-174

32. Pipeleers DG, Schuit FC, In't Veld PA et al. (1985) Interplay of nutrients and hormones in the regulation of insulin release. Endocrinology 117: 824-833

33. Lernmark $\AA$, Sehlin J, Täljedal I-B (1975) The use of dispersed pancreatic islet cells in measurements of transmembrane transport. Anal Biochem 63: 73-79

34. Thorens B, Sarkar HK, Kaback HR, Lodish HF (1988) Cloning and functional expression in bacteria of a novel glucose transporter present in liver, intestine, kidney, and $\beta$-pancreatic islet cells. Cell 55:281-290

35. Inagaki N, Yasuda K, Inoue G et al. (1992) Glucose as regulator of glucose transport activity and glucose-transporter mRNA in hamster beta-cell line. Diabetes 41: 592-597

36. Yasuda K, Yamada Y, Inagaki N et al. (1992) Expression of GLUT1 and GLUT2 glucose transporter isoforms in rat islets of Langerhans and their regulation by glucose. Diabetes 41: 7681

37. Tal M, Thorens B, Surana M et al. (1992) Glucose transporter isotypes switch in T-antigen transformed pancreatic $\beta$ cells growing in culture and in mice. Mol Cell Biol 12: 422-432

38. Katagiri H, Asano T, Ishihara H et al. (1992) Replacement of intracellular C-terminal domain of GLUT1 glucose transporter with that of GLUT2 increases $V_{\max }$ and $\mathrm{K}_{m}$ of transport activity. $J$ Biol Chem 267:22550-22555

39. Salas J, Salas M, Vinuela E, Sols A (1965) Glucokinase of rabbit liver: purification and properties. J Biol Chem 240:1014-1018

40. Purrello F, Buscema M, Rabuazzo AM et al. (1993) Glucose modulates glucose transporter affinity, glucokinase activity, and secretory response in rat pancreatic $\beta$-cells. Diabetes 42 : 199 205

41. Davagnino J, Ureta T (1980) The identification of extrahepatic "glucokinase" as N-acetylglucosamine kinase. J Biol Chem 255: 2633-2636

42. Meglasson MD, Burch PT, Berner DK, Najafi H, Vogin AP, Matschinsky FM (1983) Chromatographic resolution and kinetic characterization of glucokinase from islets of Langerhans. Proc Natl Acad Sci USA 80: 85-89

43. Gorus FK, Malaisse WJ, Pipeleers DG (1984) Differences in glucose handling by pancreatic A- and B-cells. J Biol Chem 259: 1196-1200

44. Matschinsky FM, Pagliara AS, Stillings SN, Hover BA (1976) Glucose and ATP levels in pancreatic islet tissue of normal and diabetic rats. J Clin Invest 58: 1193-1200

45. Reyes A, Cardenas ML (1984) All hexokinase isoenzymes coexist in rat hepatocytes. Biochem J 221: 303-309

Received: 7 April 1993

and in revised form: 15 June 1993

Dr. Y.Oka

Third Department of Internal Medicine

Faculty of Medicine

University of Tokyo

7-3-1 Hongo, Bunkyo-ku

Tokyo 113

Japan 